\title{
Intercultural Communicative Competence
}

\author{
Chunhong Zhou (Corresponding author) \\ Foreign Languages Department, Beijing Sport University, China \\ North Zhong Guan Cun Street, Haidian District, Beijing, 100084, China \\ E-mail: Rona402@126.com
}

Carol Griffiths

Yeditepe University, Istanbul, Turkey

Received: March 30, 2011

Accepted: April 11, 2011

Published: December 1, 2011

doi:10.5539/ells.v1n2p113

URL: http://dx.doi.org/10.5539/ells.v1n2p113

\begin{abstract}
This paper reports on a survey conducted at a university in Beijing, China into students' intercultural knowledge. Surveys with both close-ended and open-ended questions were distributed to the students and questionnaires with open-ended questions were also sent to the international teachers. By means of quantitative and qualitative research methods, this paper (a) analyzes the problems the surveyed students have with their intercultural communicative competence (b) examines the reasons for the students' failures in intercultural communication and (c) explores what intercultural knowledge should be taught in class.
\end{abstract}

Keywords: Intercultural communicative competence, Intercultural communication, Intercultural knowledge

\section{Introduction}

In a world of increasing internationalization, it is commonly accepted that learning a foreign or second language does not simply mean grasping academic study, but more appropriately focuses on learning a way of communicating. Communication in the real world is never out of context, and because culture is a part of context, communication is seldom culture-free. Language and culture have always been closely bound, and thus, it is increasingly recognized that language learning and learning about the target cultures cannot be separated (Kramsch 1993; Valdes 1986).

In the modern second language classroom the target cultures should play an essential role in language learning. However, students' knowledge about the target cultures often seems very limited. This paper reports on a survey conducted at a university in Beijing, China which looked at students' intercultural knowledge in order to analyze the problems the surveyed students have with their intercultural communicative competence and the essential reasons that resulted in the students' failures in intercultural communication. It also endeavors to explore implications for classroom practice.

\section{Literature Review}

\subsection{The definition of culture}

Culture is always a difficult concept to define and is particularly hard to separate from concepts such as ethnicity and nationality. In its anthropological sense, culture is regarded as any of the customs, worldview, language, kinship systems, social organization, and other taken-for-granted day-to-day practices of a people which set that group apart as a distinctive group (Scollon and Scollon 2000).

Many different metaphors have been used to describe culture. For example, Weaver (1993) has described culture as an iceberg, where only about one-seventh is visible, while the rest is under water and non-observable. Culture has been considered as "'glue' that binds a group of people together" (Brown 1994, p.163). Hofstede (1997, p.4) has coined the vivid definition of culture as the "software of the mind". Often individuals cannot be defined exclusively within one cultural category and as members of one group only; they may belong to many different sub-groups. It is common for individuals to have dual or even multiple cultural, ethnic, and/or linguistic origins as well as nationalities. This can change throughout a lifetime. Considering the complicated components of culture, Bhabha (1994) used the concept of hybrid cultures and personalities. 


\subsection{Intercultural communicative competence}

In Tesoriero's (2006) view, differences such as values, attitudes, culture, ethnicity, social practices, political beliefs, sexuality and religion obviously influence people all around the world who ascribe various meanings to their surroundings according to their individual attitudes. In recent years considerable research has been conducted into these differences and as a result of these studies the concept of "intercultural communicative competence" has emerged.

Intercultural competence which is often considered to be a subfield of "communicative competence" (Deardorff 2006). Intercultural competence, which is the ability to change one's knowledge, attitudes, and behaviors so as to be open and flexible to other cultures, has become a key issue in the globalized society of the 21 st century (Alred and Byram 2002). According to Huang, Rayner and Zhuang (2003), a person who has intercultural competence can develop relationships with people from different cultures, manage to solve complicated conflicts by crossing the barriers that arise as a result of cultural differences and improve the ability to do business with counterparts from different cultures. Taylor (1994) defines intercultural competence as a transformative process through which the stranger develops adaptive capacity, altering his/her perspective to effectively understand and adapt to the demands of the host culture. Hence, learning to deal with different cultures effectively requires cultural awareness, communicative competence, personal attitudes like empathy and flexibility, self awareness and understanding others' values, norms and beliefs.

Communicative competence on the other hand is defined by Chen (1990) as the ability to effectively and appropriately carry on communication behavior to elicit a desired response in a specific environment. The definition indicates that communication is two-sided for competent individuals who can both transfer their own ideas and fulfill their own communication goals. According to Canale (1983) communicative competence includes four competencies: grammatical competence (i.e. knowledge of the language code); sociolinguistic competence (i.e. knowledge of the socio-cultural rules of use in a particular context); strategic competence (i.e. knowledge of how to use communication strategies to handle breakdowns in communication) and discourse competence (i.e. knowledge of achieving coherence and cohesion in a spoken or written text).

The combination of intercultural competence and communicative competence is defined by Chen and Starosta (1998) as the ability to effectively and appropriately execute communication behaviors that negotiate each other's cultural identity or identities in a culturally diverse environment. Their definition has highlighted three basic components for intercultural communicative competence as intercultural sensitivity (affective process), intercultural awareness (cognitive process), and intercultural adroitness (behavioral process), which basically refers to our verbal and non-verbal factors of communication mentioned above as a part of intercultural competence.

\subsection{Studies of students' intercultural communicative competence}

Sebnem, Dicle and A. Guldem (2009) analyzed the intercultural sensitivity levels of university students and the contribution of education and intercultural experience on the formation of intercultural communicative competence. Their study has revealed that students' respect for different cultures improves with the level of engagement in international interactions. Marek (2009) pointed out in his research that the target language culture is an essential component in the process of effective language learning and teachers are strongly recommended to cover more of the target language culture in the classroom. Hence, students' respect for cultural differences can be greatly improved in the process of language learning in the classroom if the teachers incorporate culture into the language teaching process. Hao and Zhang (2009) surveyed Chinese college students' intercultural competence and discovered that despite the fact that the surveyed students had been engaged in English learning for at least 12 years, they were not successful in cultivating their intercultural awareness and frequently failed to respond appropriately in intercultural communication contexts

\section{The Study: Procedure}

The current study aimed to explore the following four questions:

(1) What are the problems students have with intercultural communicative competence?

(2) What are the reasons for failures in intercultural communication?

(3) What intercultural knowledge should be taught in class?

(4) What are the appropriate approaches to culture teaching in class?

\subsection{Participants}

The present study was conducted at Beijing Sport University, China. The 102 participant students are non-English majors and non-sports majors studying a college English course in their second semester of the first year in the 
university. They were majoring in sports rehabilitation and divided into two classes. Approximately $60 \%$ of the students were male and $40 \%$ were female, and their age ranged from 17 to 20 .

In addition, in order to find out the barriers that hinder college students from communicating with people from foreign countries, questionnaires were also sent by email to seven international teachers who were teaching or had taught at Beijing Sport University. Their length of teaching in China ranged from two years to eleven years and the average length of teaching in China was five years.

\subsection{Data collection}

For the purpose of the study, students were gathered together and a survey with ten multiple choice questions and three open-ended questions was distributed, completed and returned. Instructions were given both in English and Chinese in order to ensure that students understood what they were required to do. The research purpose of the survey was explained so that students were assured that it had nothing to do with their final scores of this course. Students were observed when they were working on the survey, questions were answered as they arose, and surveys were collected as they were completed. Seven international teachers completed the questionnaires and sent them back by email.

\subsection{Instruments}

In order to obtain both quantitative and qualitative data, this study used two instruments.

(A) Questionnaire 1. In order to get both quantitative and qualitative data, a questionnaire on knowledge of western traditions and customs was distributed to 102 students. There were 10 questions (some questions were composed of two parts) on customs which differ in China and the West and suggested answers were provided for the students to choose from. The questions applied in the survey were excerpted from the survey used by He (1999) in his study. In addition, students were required to answer three open-ended questions related to the barriers they came across when communicating with foreigners. Biographic details including their Chinese name, student number, gender, e-mail address and age were asked for.

(B) Questionnaire 2. In order to obtain more qualitative data, a questionnaire was also sent to seven international teachers by email. They were asked to answer the following four questions:

Q1: What barriers have you encountered when communicating with Chinese students in class and out of class?

Q2: What should Chinese students learn about western culture to improve their intercultural communicative competence?

Q3: How can Chinese students effectively improve their intercultural communicative competence?

Q4: What do you think Chinese English teachers should do in class to help the students improve their intercultural communication skills?

\subsection{Data analysis}

Quantitative data from the survey were entered into Excel and examined for the mean score of the students' performance in answering the 10 questions and for the average score of each question. The qualitative data from the open-ended questions of the survey and from the questionnaire sent to the international teachers were subjected to a content analysis, which investigated the problems the students encountered in their communication with foreigners from both the students' and international teachers' points of view. The qualitative data also provided some useful insights into how to improve the students' intercultural competence from the international teachers' view.

\section{The study: Results}

The results produced by this study fall into two categories: quantitative and qualitative. These different types of results will initially be reported separately before being discussed.

\subsection{Quantitative survey results}

Regarding the students' performance in completing the 10 questions, Table 1 (at the end of the article) shows that the average score is 6.20 (one question is worth one point). It also indicates that of the questions asked, the highest average score is for question 5: "Should a Westerner call and make an appointment before visiting somebody?" (the average score $=0.80$ ). It means that most students know that before visiting somebody, Westerners usually call and make an appointment. Although not as high as question 5, students also got a relatively high score for question 3: "What does a Westerner mean when he or she shrugs" (the average score $=0.74$ ). Scores are also relatively high for question 4: "What color does a western bride usually wear at the wedding" (the average score $=0.72$ ). The lowest average score is for question 6: "In the West, does the host show the guests around the house?" (the average 
score=0.42). The other two questions to which most of the students gave wrong answers are Question 2: "Is it appropriate for Westerners to hold hands or wrap arms around each other with friends of the same gender?", (the average score $=0.43$ ) and question 8: "A Westerner is at a friend's house. He is thirsty. Is it appropriate for him to ask for drinks?" (the average score $=0.51$ ). Among all the surveyed students, none of them provided correct answers to all of the ten questions.

\subsection{Qualitative survey results}

In the process of reviewing the open-ended questions in the survey, some insightful answers provided by the students were noteworthy. For question 1 "What barriers have you encountered in the process of communicating with people from English-speaking countries?" enlightening answers included:

When communicating with the foreigners, I don't catch what they are saying and they don't understand what I am saying. Because my poor English, I am afraid of communicating with foreigners. The difference between Chinese culture and western culture can cause misunderstanding easily.

My vocabulary size is not large and I could not catch the flow of speaking of the foreigners. In addition, I can not understand the slang they use. My oral English is not accurate and I have to hammer out the words I will say because I am afraid of violating the taboos when I am communicating with foreigners.

I cannot get rid of the habit of Chinese-English translation communication style. And I usually cannot find out proper words to express what I mean and the words I used caused trouble for the foreigners to understand me.

When the foreigners are speaking English they are very relaxed and they don't follow the right grammatical rules occurring in the English textbooks in China. I cannot understand whether the purpose for me to learn English is for analyzing the sentence structure or for communication. Why do the Chinese English learners always pay so much attention to the stiff grammar and regard it as the Bible for learning English while the native speakers regard it senseless?

When asked "What kind of intercultural knowledge do you want to get most in English classes?" most students considered sports, politics, economy, the differences between Chinese and western culture, the social system of western countries, festivals, entertainment, religion and legislation in western countries as the crucial knowledge for them to grasp in order to improve their intercultural communication skills. Three wrote:

I want to know some knowledge about sports, politics and economy in the western countries that are not included in the textbook.

I want to know about the westerners' customs, etiquettes, food, important festivals, values, life style and some slang they usually use in their communication. What's more, being well informed of the updated entertainment and political news is important for me to communicate with the foreigners.

I think classical English movies, popular culture, politics, religion, laws in English-speaking countries are very important for me. Besides, I want to get some skills to communicate with the western people, fore example, what I should avoid mentioning, the taboos, between our communication.

In answer to the question "What do you think the teacher should do in English classes to help you improve your intercultural communication skills", a great number of students suggested that teachers should focus less on grammatical rules and more on communication. Besides, English teachers should arouse the students' intercultural awareness, analyze cultural differences in class, and create various scenarios for them to practice intercultural communication in the simulated social context. Three of them noted:

I hope that the teachers can show American political news in class and organize some discussions about them so that we can know about the current affairs in the western countries, play some movies that reflect the mainstream cultures in the western countries and explain the key culture differences between them and the Chinese cultures.

In my opinion, the teachers should give up the main objective of grammar teaching in class. They need to teach us how to communicate with the foreigners, distribute some materials about the western cultures to us, and explain the idioms and the contexts for us to use them.

It is necessary for the teachers to help us make some foreign friends, introduce some websites for us to be exposed to the current affaires, fashions, updated cultural events in the western countries. The teachers should reserve time for explaining western cultures in class so that the students can get more touch with them. 


\title{
4.3 Teachers' questionnaire results
}

Questionnaires were also sent to seven international teachers to investigate the problems they have encountered when communicating with students and seeking their suggestions for improving students' intercultural communicative competence. When asked "What barriers have you encountered when communicating with the Chinese students in class and out of class?" two of them considered language as the first and foremost barrier. They wrote on their questionnaires:

Most students are afraid to speak or didn't understand the question or are afraid they might make a mistake and be embarrassed. Many students are poorly informed about current events in world politics, economics and social issues, so they have little to say. Many students are afraid to discuss controversial topics. Another problem is "Chinglish", like "How to say?", "I have ever gone there." One of the biggest barriers is slow listening comprehension. I must speak slowly and often repeat sentences in class.

Obviously the language. And a tendency to be shy which is their way of showing respect. And the tendency to be reluctant to speak in case they make mistakes and lose face.

When the international teachers were asked "What should Chinese students learn about western culture to improve their intercultural communicative competence? Most of them regarded the common social expressions, slang, the social system, religion and values as the priority. Their suggestions included:

Students need to train their ears to understand the different accents of English speaking countries: RP, cockney, Irish, Australian etc. as well as other Asian and African accents. Students also need to train their ears to understand common social expressions, slang, and reductions which are typical in American English.

Biblical moral and ethics; democratic freedom, individualism (to understand why foreigners behave/think the way they do)

When asked "By what way can Chinese students effectively improve their intercultural communicative competence?" In addition to going overseas, they suggested:

Some good tools for improving communication are: watch movies and TV shows without subtitles, join English corners, foreign teacher's office hours, speech contests and debates, and find a friend from a foreign country.

Students should be in contact with more foreigners, keep up to date with current events, especially international affairs, learn and be aware of the differences in culture but not be so caught up with the typical stereotypes -- not everyone is the same, and speak and think in English

The questionnaire also investigated the international teachers' advice for Chinese English teachers to help the students improve their intercultural communication skills. Among all the answers provided to the question "What do you think Chinese English teachers should do in class to help the students improve their intercultural communication skills?" the international teachers all recommended that the Chinese English teachers should improve their own English and broaden their knowledge about western cultures. Two of them wrote:

\begin{abstract}
Most Chinese English teachers speak and teach Chinglish in the classroom and use textbooks riddled with Chinglish. Teachers need to correct their own Chinglish, and then help students fix their Chinglish. It would be much more efficient to lecture less and make more time for student speeches, discussion groups, debates, games and role playing.
\end{abstract}

The teachers should try to practice communicative language teaching techniques, though this is difficult with large classes, low English levels etc.

\section{Discussion}

According to the results, most students in this study do not have a high intercultural communicative competence. Furthermore, since more than half of the students provided incorrect answers to question 2 (regarding homosexuality), question 6 (show around the house) and question 8 (ask for drinks), it suggests that many students are unclear about the differences between Chinese and western culture and lack knowledge about the common western customs and values. Only half of the students know it is appropriate for westerners to ask for drinks when thirsty, although there is a relatively high score for questions No. 3, No. 4, and No. 5. The results of this study accord with He's study (1999). According to He, regarding the sources of information, English classes are the chief information provider for verbal communication (Question 1), western TV and movies for non-verbal communication (Question 2 to 3), while the combination of the two provide information on etiquette (Question 4-10). It therefore 
follows that teachers should teach the students some verbal communication skills in class and should not miss any opportunity to explain the customs, etiquettes and other cultural points exemplified in western TV shows and movies. The results from the survey indicate that at least half of the students have poor intercultural knowledge, which is in accordance with Hao and Zhang's (2009) findings.

According to the results from the students' answers to the questions in the survey, most of the students considered their poor listening comprehension, lack of knowledge about differences between western and Chinese culture, teachers' grammar-focused teaching methods and their habit of thinking in Chinese accounted for the barriers hindering them from communicating with foreigners smoothly and efficiently. Recent research evidence also suggests that lack of intercultural awareness and teachers' inadequate covering of intercultural knowledge in class are the main factors to affect students' intercultural communicative competence (Hao and Zhang 2009; Marek 2008). Students are eager to acquire knowledge about sports, politics, religion, economics, customs, etiquette, festivals, entertainment, values, life style, popular culture and laws in western countries as well as slang, common idioms and taboos. These components of culture were suggested as essential for improving the students' intercultural communicative competence by Zhou and Cui (2007). Regarding students' expectations of teachers, most students hope that, rather than focusing on grammar and text structures, teachers can spend more time on teaching intercultural communication skills and reserve time for students to practice these skills under various scenarios, explaining mainstream cultures in western countries as revealed in movies, current affairs, etc. and cultivate students' awareness of cultural differences.

The qualitative data produced from the questionnaires distributed to the international teachers indicated that the international teachers regarded the Chinese students' Chinglish, introverted character and poor listening comprehension as the biggest barriers impeding communication with Chinese students. And they suggested that Chinese students should be trained to understand different accents of English speaking countries, common social expressions, slang, religion, social systems such as democratic freedom and individualism and the reason for foreigners' ways of behavior and thinking. The importance of religion in intercultural communication is also commented on by Scollon and Scollon (2000) who consider that beliefs, values, and religion have played a very significant role in the communication between Asians and Westerners over the past few centuries. Some of the suggested elements for improving students' intercultural communicative competence are identical to those students desired to learn as revealed in the survey. Besides, as to the tools for improving the Chinese students' intercultural communicative competence, feasible recommendations introduced by the international teachers include watching movies and TV shows without subtitles, joining some English activities, communicating with people from English-speaking countries, developing a strong sensitivity to cultural differences, getting out of the trap of the typical stereotypes and getting into a habit of thinking in English when communicating with foreigners. Their suggestions account for the reason for the Chinese students' poor listening comprehension because students had an ingrained habit of thinking in Chinese and decoding Chinese into English before expressing their ideas and decoding English into Chinese before digesting the ideas the native English speakers expressed. The surveyed students agreed that they were used to thinking in Chinese, which was one of the biggest barriers when communicating with target language speakers. Concerning suggestions for Chinese teachers to help promote the students' intercultural communicative competence, the international teachers agreed that Chinese teachers should first correct their own Chinglish and use textbooks with authentic English. Then they could help students correct their Chinglish by lecturing less and reserving more time for simulated intercultural activities. Therefore, in order to improve students' intercultural communicative competence, teachers should endeavor to practice communicative language teaching techniques.

\section{Pedagogical Implications}

According to the results from the survey, students' intercultural knowledge is not high, so teachers should emphasize the teaching of culture. Since class is the main resource for the students' intercultural knowledge, teachers should introduce current affairs, customs, etiquettes, laws, social systems in western countries, show movies, TV plays and documentaries etc. in class and recommend some culture-focused books or magazines to the students for further reading out of class. Meanwhile, in order to direct students, teachers should correct their Chinglish, have their intercultural knowledge richened, and develop their sensitivity towards cultural differences. When imparting western cultures to students, it is essential for teachers to analyze the differences between Chinese and western culture so that the students know how to empathize in the intercultural communication process. It is also important that teachers avoid cultural stereotypes in their culture teaching since different races and ethnicities differ in culture.

As learners and receivers of intercultural knowledge and as future international citizens, students should realize the importance of being well informed about intercultural knowledge. In the meantime, they should seize every opportunity to communicate with foreigners by making foreign friends including foreign cyber friends, attending 
international teachers' office hours, joining English corners on college campuses and extending their reading after class etc. In addition, students should learn how to empathize when they are communicating with foreigners and avoid ethnocentrism by always showing respect for the foreigners' cultures.

\section{Questions for Further Research}

The results of the current study suggest a number of questions for further research:

1) Since the current study only asked the students a small number of questions, which may affect the reliability of the results, the development of a revised instrument to test the students' intercultural communicative competence is needed.

2) How can teachers carry on culture teaching in class within limited class hours, since most students in Chinese universities only take four hours of English classes per week, and the teaching content should cover listening, speaking, reading, writing and translation?

3) How can curricula be designed to include intercultural communication?

4) Since many Chinese English teachers lack intercultural knowledge, more studies are needed regarding how to enrich the teachers' intercultural knowledge and how to develop their cultural sensitivity by means of teacher training programs.

\section{Conclusion}

The findings of this research indicate that most college students do not have rich intercultural knowledge and their intercultural communicative competence is not high because of the lack of knowledge about cultural differences, the teachers' Chinglish, grammar-focused teaching methods and the students' habit of thinking in Chinese. In order to develop students' intercultural communicative competence, it is crucial for the teachers to correct their Chinglish, get their own intercultural knowledge enriched, and develop their sensitivity to cultural differences. Concerning the intercultural knowledge which should be taught in class, it is necessary for teachers to cover current affairs, sports, customs, etiquettes, laws, religion, social systems, values, beliefs, concept of time in western countries, show movies, TV plays and documentaries in class and recommend some culture-focused books or magazines to students for further reading out of class. Teachers should also avoid cultural stereotypes.

Results from the research also show that it is vital for students to be aware of the importance of cultural differences for intercultural communication and to show respect for these differences. With the purpose of developing their intercultural communicative competence, students should take every possible opportunity to communicate with foreigners, to get the most out of international teachers' office hours, to join the English corners on college campuses, and to actively participate in simulated intercultural communication activities in class. It is also necessary for them to empathize with foreigners and avoid ethnocentrism when communicating with them.

\section{References}

Alred, G., \& Byram, M. (2002). Becoming an Intercultural Mediator: A Longitudinal Study of Residence Abroad. Journal of Multilingual and Multicultural Education, 23, 339-352. http://dx.doi.org/10.1080/01434630208666473

Bhabha, H. (1994). The Location of Culture. London: Routledge.

Brown, A. (1994). The advancement of learning. Educational Researcher, 23(8), 4-12. http://dx.doi.org/10.2307/1176856

Canale, M. (1983). From Communicative Competence to Communicative Language. Pedagogy. In J. C. Richards and R. W. Schmidt (eds.), Language and Communication. London: Longman, 2-27

Chen, G. M. (1990). ICC: Some Perspectives of Research. Paper presented in the Annual Meeting of the Eastern Communication Association.

Chen, G. M., \& Starosta, W. J. (1998). Foundations of Intercultural Communication. Boston: Allyn and Bacon.

Deardorff, D. K. (2006). Identification and Assessment of Intercultural Competence as a Student Outcome of Internationalization. Journal of Studies in International Education. 10(3), 241-266. http://dx.doi.org/10.2307/1176856

Hall, J. K. (2002). Teaching and Researching Language and Culture. London: Pearson Education.

Hao, Q, H., \& Zhang, Y. (2009). A Survey on Chinese College Students' Intercultural Literacy. US-China Foreign Language. 7(7), 1-5

He, M. (1999). The Structure of Culture and Intercultural Communication Studies - Some Critical Comments. Aspects of Intercultural Communication - Proceedings of China's $2^{\text {nd }}$ Conference on Intercultural Communication. 
Beijing: Foreign Language Teaching and Research Press. pp. 108-115

Huang, Y., Rayner, C., \& Zhuang, L. (2003). Does Intercultural Competence Matter in Intercultural Business Relationship Development? International Journal of Logistics, 6(4), 277-288

Hofstede, G. (1980). Culture's Consequences: International Differences in Work Related Values. Beverly Hills. CA: Sage Publications.

Kramsch, C. (1993). Language Study as Boarder Study: Experiencing Difference. European Journal of Education, 28(3), 349-358. http://dx.doi.org/10.2307/1503764

Marek, D. (2008) The Place of the Target Language Culture in the Language Classroom: A Few Modest Proposals. In M. Pawlak (ed.), Investigating English Language Learning and Teaching. Poznań: Adam Mickiewicz University Press. pp. 347-356

Scollon, R., \& Scollon, S. (2000). Intercultural Communication: A Discourse Approach. Beijing: Foreign Language Teaching and Research Press.

Sebnem, P, Dicle Y., \& Guldem A. (2009). Intercultural Communication competence: A Study about the Intercultural Sensitivity of University Students Based on Their Education and International Experiences. Paper presented in the European and Mediterranean Conference on Information Systems.

Tesoriero, F. (2006). Personal Growth towards Intercultural Competence through an International Field Education Programme. Australian Social Work, 59(2), 126-140. http://dx.doi.org/10.1080/03124070600651853

Taylor, E. (1994). Intercultural Competency: A Transformative Learning Process. Adult Education Quarterly, 44, 154-174. http://dx.doi.org/10.1177/074171369404400303

Valdes, J. M. (1986). Culture Bound: Bridging the Cultural Gap in Language Teaching. Cambridge, UK: Cambridge University Press.

Weaver, G. R. (1993). Understanding and Coping with Cross-cultural Adjustment Stress. In M. Paige (ed.), Education for the Intercultural Experience, Second Edition. Yarmouth, ME: Intercultural Press. pp. 137-167

Zhou, B., \& Cui, F. (2007). On the Promotion of Intercultural Communication competence. Sino-US English Teaching, Vol.4, 77-81

Table 1. Quantitative results

\begin{tabular}{|l|l|l|}
\hline Question No. & Question & Average score for each question \\
\hline 1 & Sneeze & 0.66 \\
\hline 2 & Homosexual & 0.43 \\
\hline 3 & Shrug & 0.74 \\
\hline 4 & Bride's gown & 0.72 \\
\hline 5 & Phone & 0.80 \\
\hline 6 & Show around & 0.42 \\
\hline 7 & Sit on the bed & 0.67 \\
\hline 8 & Ask for drinks & 0.51 \\
\hline 9 & Finish food & 0.61 \\
\hline 10 & Gift & 0.65 \\
\hline Overall average score & & 6.20 \\
\hline
\end{tabular}

Appendix 1: Questionnaire on the Intercultural Knowledge of the Chinese College Students

\begin{tabular}{|cc|}
\hline Biographic Data about You & female ( ) \\
Gender: male ( ) & Student No. \\
Chinese name in Pinyin & Email address \\
Age & \\
\hline
\end{tabular}


I. The following questions are a test of your knowledge and understanding of the culture of English-speaking countries. Choose what you think is the appropriate answer.

1. When a westerner sneezes, what should he or she say? ( )
A. He or she should not say anything
B. Excuse me
C. do not know / not sure

What should the person close by say?
A. He or she should not say anything
B. Excuse me
C. do not know / not sure

2. Is it appropriate for the westerners to hold hands or wrap arms around each other with friends of the same gender?
A. Yes
B. No
C. do not know / not sure

Do you know why or why not? (
A. because it is childish to do so
B. because it means friendship
C. because it could be a sign of homosexual in the west

3. What does a westerner mean when he or she shrugs? ( )
A. I will think about it
B. Sorry, I don't know / I can't help you
C. Do not know/ not sure

4. What color does a western bride usually wear at the wedding? ( )
A. White
B. Red
C. Pink
D. do not know/ not sure

5. Should a westerner call and make appointment before visiting somebody? ( )
A. Yes, he must
B. No, he needn't
C. do not know / not sure

6. In the west, does the host show the guests around the house? ( )
A. Yes
B. Usually not
C. Do not know / not sure

7. When someone visits a friend of the opposite sex, is it proper to sit on the friend's bed? ( )
A. Yes, it is
B. No, it isn't
C. Do not know / not sure

8. A westerner is at a friend's house. He is thirsty. Is it appropriate for him to ask for drinks? ( )
A. Yes
B. No, he should wait to be offered drinks
C. Do not know or not sure

How should the visitor react when being offered a drink? ( )
A. Decline a few times to be polite
B. Accept it and say "Thank you"
C. Accept it and say nothing
D. Do not know or not sure

9. In the west, is it appropriate for the host to pick food for the guest and push him or her to eat more? ( )
A. Yes
B. No
C. Do not know or not sure

Is the guest supposed to finish all the food in his or her plate and the drink in his or her cup? ( )
A. Yes
B. No
C. Do not know or not sure

10. What is the response of a westerner when he or she receives a gift from someone? ( )
A. Say "Thank you" and put it aside
B. Say "Thank you" and open it right away
C. Do not know or not sure

\section{Answer the following questions.}

1. What barriers have you encountered in the process of communicating with people from English-speaking countries?

2. What kind of intercultural knowledge do you want to get most in English classes?

3. What do you think the teacher should do in English classes to help you improve your intercultural communication skills? 


\section{Appendix II}

\section{A questionnaire about the College Students' Intercultural Communicative competence}

This questionnaire is to investigate the barriers you have encountered when communicating with the Chinese students and your suggestions for them to improve their intercultural communication skills. The results of the questionnaire will be used in the research only and you personal information will be kept secret.

Name: Length of teaching in China

1. What barriers have you encountered when communicating with the Chinese students in class and out of class?

2. What should the Chinese students learn about the western culture to improve their intercultural communicative competence?

3. By what way can the Chinese students effectively improve their intercultural communicative competence?

4. What do you think the Chinese English teachers should do in class to help the students improve their intercultural communication skills? 